Historic, archived document

Do not assume content reflects current scientific knowledge, policies, or practices. 



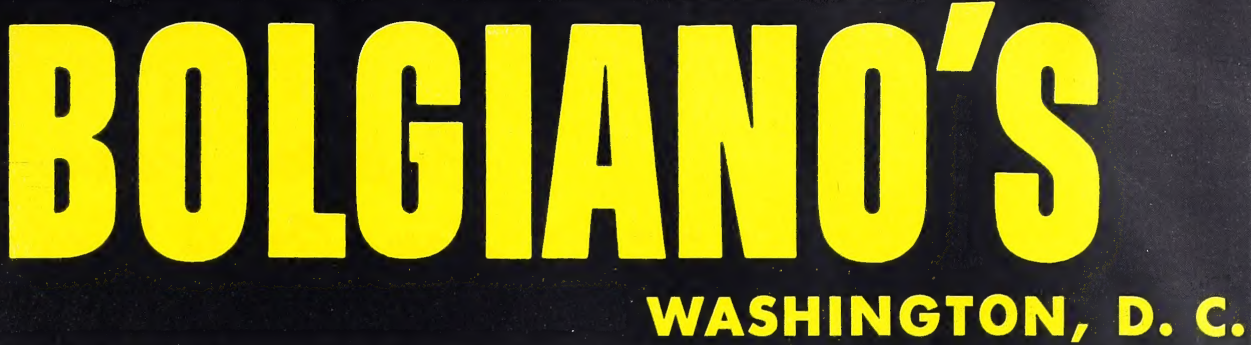

\section{BULBS, PLANTS AND LAWN SEEDS FOR FALL 1962 PLANTING}

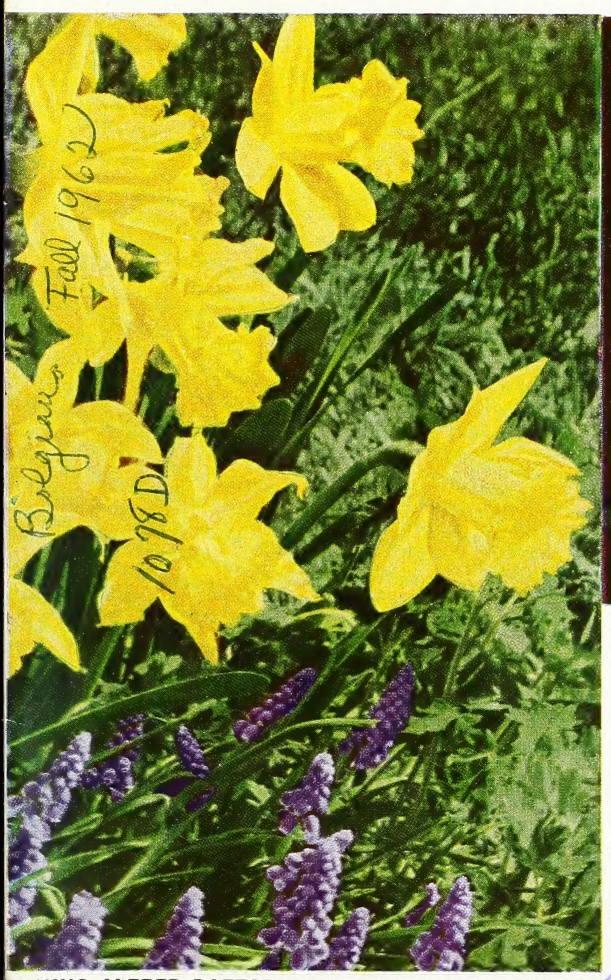

KING ALFRED DAFFODILS AND GRAPE HYACINTHS

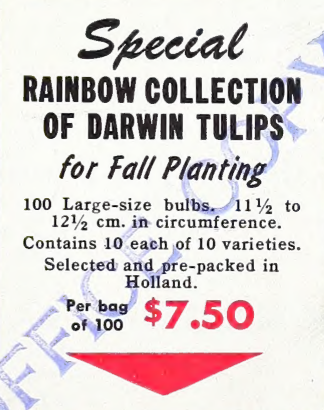

GIANT AMARYLLIS

Separate colors - see page 7

CROCUS - see page 8

AAINBOW COLLECTION OF DARWIN TULIPS for Fall Planting

100 Large-size bulbs. $11 \frac{1 / 2}{2}$ to Contains 10 each of 10 varieties.

Selected and pre-packed in

Per bag $\$ 7.50$
of 100 


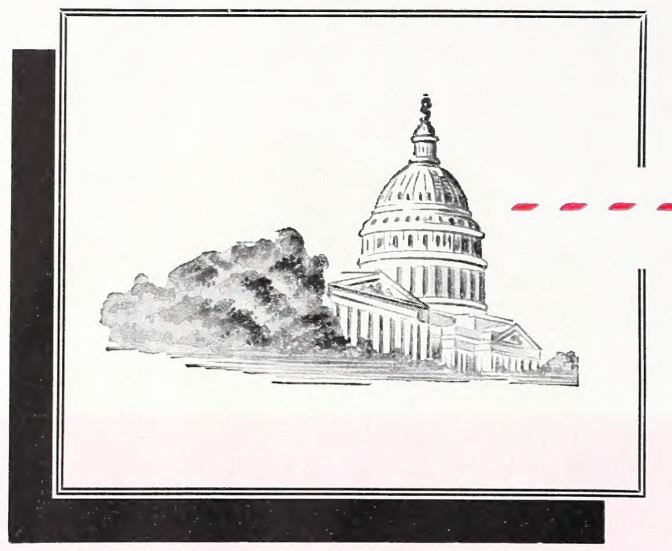

\section{BOLGIANO'S Capital Park Lamen Grass Seed "The Nation's Pride!"}

Truly a top-grade lawn mixture, containing a carefully selected, well-balanced blend of highest quality, recleaned seed to produce a fine lawn in the Washington, Maryland and Virginia area. Capitol Park Lawn Seed is the result of our 73 years' experience. It has been thoroughly tested and proved and will produce fine-bladed, deep-rooted grasses that are so necessary for a beautiful year-round turf.

CAPITOL PARK
LAWN
GRASS SEED $\begin{cases}\text { Lb. } & \$ 0.95 \\ 5 \text { Ibs. } & 4.45 \\ 25 \text { Ibs. } & 21.00 \\ 50 \text { lbs. } & 39.95 \\ 100 \text { lbs. } & 79.50\end{cases}$

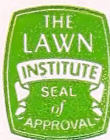

OUR LAWN MIXTURES HAVE BEEN AWARDED THE LAWN INSTITUTE'S SEAL OF APPROVAL FOR THE WASHINGTON, MARYLAND AND VIRGINIA AREAS.

COVERAGE OF 5 LBS.: 1500 SQ. FT. FOR NEW LAWNS, 2500 SQ. FT. FOR OLD LAWNS.

Ask for Bolgiano's "Handy Guide to a Beautiful Lawn"

Use PREMIER PEAT MOSS for improving all types of soils

\section{BOLGIANO'S WHITE HOUSE \\ SHADY LAWN GRASS SEED}

Washington is often called the "city of trees." Because of the shade they cast, these magnificent trees are frequently a cause of concern to home owners. But, thanks to Bolgiano's White House Shady Lawn Grass Seed, you can enjoy a beautiful turf in shady spots that will match the turf of our Capitol Park Lawn Grass in the sun. Through experimentation with grasses best adapted for growing in the shade in the Washington, Maryland and Virginia area, this formula was proved.

25 lbs. \$21.00; 50 lbs. \$39.95; 100 lbs. \$79.50

\section{BOLGIANO'S PERMA-GREEN LAWN GRASS SEED}

Another of our popular lawn grass seed mixtures is Perma-Green, an all-purpose blend of the finest Kentucky Blue, Merion Kentucky Blue, and Pennlawn Creeping Red Fescue grasses. This blend is capable of producing a dense, velvety lawn resistant to dry summer weather.

Lb. $\$ 1.35 ; 5$ lbs. $\$ 6.50$;

25 lbs. \$29.75; 50 lbs. $\$ 58.00$
MERION KENTUCKY BLUE GRASS. Accepted as a superior strain of Kentucky Blue Grass for use on lawns and turf. It has the characteristics of regular Kentucky Blue Grass plus the added advantage of sturdiness, drought and disease resistance. Lb. $\$ 1.85 ; 10$ lbs. $\$ 18.00$.
BOLGIANO'S DELUXE BLEND LAWN GRASS MIX TURE $(55 \%$ Merion Formula). Contains sturdy Merion Kentucky Blue Grass with Pennlawn Fescue. These permanent grasses will give a long-lasting turf. Lb. \$1.75; 3 Ibs. \$5.10; 10 Ibs. $\$ 16.50$.

\section{OTHER BOLGIANO LAWN GRASSES}

Ky. Blue Grass. Lb. 90c.; 10 Ibs. $\$ 8.75$.

Highland Bent. Lb. 95 c.; 10 Ibs. $\$ 9.00$.

Penncross Bent. Lb. $\$ 8.25 ; 10$ Ibs. $\$ 80.00$

Pennlawn Creeping Red Fescue. Lb. 90c.; 10 lbs. $\$ 8.75$.

Chewing Fescue. Lb. 85c.; 10 Ibs. \$8.00.

IIlahee Creeping Red Fescue. Lb. 90 c.; 10 Ibs. $\$ 8.75$.
Poa Trivialis. Lb. 95c.; 10 lbs. $\$ 9.00$.

White Dutch Clover. Lb. $\$ 1.35 ; 10$ lbs. $\$ 13.00$.

Ky. 31 Fescue. Lb. 50c.; 10 Ibs. $\$ 4.50$.

Rye Grass, Annual. Lb. 30c.; 10 lbs. \$2.75.

Rye Grass, Perennial. Lb. 40c.; 10 lbs. $\$ 3.75$.

ALL PRICES ARE SUBJECT TO CHANGE WITHOUT NOTICE

\section{HOW TO ORDER . . .}

For Free Delivery in D. C. and nearby Maryland and Virginia areas, phone Lincoln 7-4800 or National 8-0091.

Address All Mail to F. W. Bolgiano \& Co., 411 New York Ave., N. E., Washington 2, D. C.
Postage and Express Charges. We pay Postage east of the Mississippi on all bulb orders amounting to $\$ 9.00$ or more. If order is less than $\$ 9.00$ add $50 \mathrm{c}$ to cover postage and packing. Express charges are C. O. D.

Sales Tax must be included with remittance.

Our Terms with customers not having an account are always cash with order. We do not send nursery stock C. O. D.

F. W. BOLGIANO \& CO. INC., warrants to the extent of the purchase price that, at the time of delivery, seeds or bulbs sold are as described on the container or on the tag attached thereto within recognized tolerances. We give no other or further warranty expressed or implied.

411 New York Ave., N.E., LI. 7-4800 


\section{Make a parade of color in the Spring with}

\section{BOLGIANO'S MAY-FLOWERING TULIPS}

TOP-SIZE BULBS

$12 \mathrm{~cm}$. and up in circumference, except where noted Plant bulbs 5 to 6 inches deep, 6 inches apart

\section{DARWIN - BREEDER - COTTAGE MENDEL $\bullet$ LILY-FLOWERED • TRIUMPH}

Anjou. Darwin. Large, canary-yellow blooms with deeper sheen at the edges. Late. 3 for 55 c.; $\$ 2.05$ per doz.; $\$ 16.00$ per 100.

Annie Speelman. Ideal Darwin. Unsurpassed cream-white Tulip. An oval flower of remarkable texture. $\$ 1.40$ per doz.; $\$ 10.50$ per 100.

Aristocrat. Darwin. Soft purplish violet edged white. $\$ 1.40$ per doz.; $\$ 10.50$ per 100 .

Artist. Cottage. Outside purple and salmon-rose with green markings. A very unusual flower with pointed petals. 3 for $50 \mathrm{c}$.; $\$ 1.95$ per doz.; $\$ 15.00$ per 100 .

Charles Needham. Darwin. Very fine scarlet-red with black base. $\$ 1.40$ per doz.; $\$ 10.50$ per 100

Chinese Bandit. Breeder. Immense oval flower of Chinese-red flushed orange. Vivid yellow base. \$1.45 per doz, $\$ 11.00$ per 100

Cum Laude. Darwin. Dark campanula-violet color with slight silvery sheen at the edges. $\$ 1.40$ per doz.; $\$ 10.50$ per 100 .

Dillenburg. Breeder. A lovely late-flowering orange-terra-cotta. $\$ 1.15$ per doz.; $\$ 8.50$ per 100 .

Florence Nightingale. Darwin. Brilliant vermilion-red with small vellow base. Late. 3 for 45 c.; \$1.65 per doz.; \$12.75 per 100 . Glacier. Darwin. Pure white with ivory stamens, A tremendous, oval flower of excellent substance. Very long lasting, both in the oval flower of excellent substance. Very long lasting,
garden and when cut. $\$ 1.40$ per doz.; $\$ 10.50$ per 100.

Golden Age. Darwin. A bright golden orange giant. \$1.25 per doz.; $\$ 9.25$ per 100 .

Good Gracious. Cottage. Chinese Lantern Tulip. A blending of pink, salmon and orange on a yellow base. The rich coloring gives the effect of a lighted Chinese Iantern. $\$ 1.40$ per doz.; $\$ 10.50$ per 100.

Insurpassable. Darwin. A lovely violet. \$1.25 per doz; \$9.25 per 100.

Mamassa. Darwin. A beautiful bright buttercup-yellow. \$1.15 per doz,; $\$ 8.50$ per 100 .

Mrs. John T. Scheepers. Cottage. Yellow with fawn center. Large, deep cup. $\$ 1.40$ per doz.; $\$ 10.50$ per 100

Niphetos. Darwin. Beautiful lemon-yellow. \$1.25 per doz; \$9.25 per 100 .

Orange Wonder. Mendel. Orange-vermilion shaded brown. $\$ 1.40$ per doz.; $\$ 10.50$ per 100 .

Pandion. Darwin. A new color combination of purple with a very distinct white border. $\$ 1.40$ per doz.; $\$ 10.50$ per 100 .

Princess Elizabeth. Darwin. Soft rosy pink; very beautiful. A good forcing variety. \$1.25 per doz; ; $\$ 9.25$ per 100 .

Queen of the Night. Darwin. Large, purplish black. Bluish foliage. $\$ 1.10$ per doz,; $\$ 8.25$ per 100 .

$\$ 1.10$ per doz,; $\$ 8.25$ per 100 .
Red Shine. Lily-flowered. Dazzling scarlet-red, very large. $\$ 1.25$ per doz.; $\$ 9.25$ per 100.

Rosa Van Lima. (D) Beautiful lilac-rose edged salmon-red. $\$ 1.25$ per doz.; $\$ 9.25$ per 100.

Scarlett O'Hara. Darwin. Bright geranium-red with a distinct black base edged yellow. A fine garden variety. 3 for $40 \mathrm{c}$; $\$ 1.50$ per doz: $\$ 11.50$ per 100 .

Scotch Lassie. Darwin. Pure deep lavender with slightly reflexing petals. $\$ 1.10$ per doz.; $\$ 8.25$ per 100 .

smiling Queen. Cottage. Beautiful satiny pink edged silver on outer petals. A large and very beautiful flower commanding attention in every planting. $\$ 1.40$ per doz.; $\$ 10.50$ per 100 .

The Bishop. Darwin. Deep violet with small dull blue base and white halo. Large and lasting. $\$ 1.40$ per doz.; $\$ 10.50$ per 100 .

White Triumphator. Iily-flowered. Very large; pure white The finest Lily-flowered Tulip in existence and absolutely unforgettable. Tall; comes back well for several years. Selected from our trials. $\$ 1.25$ per doz.; $\$ 9.25$ per 100

MAY-FLOWERING TULIPS continued on page 4

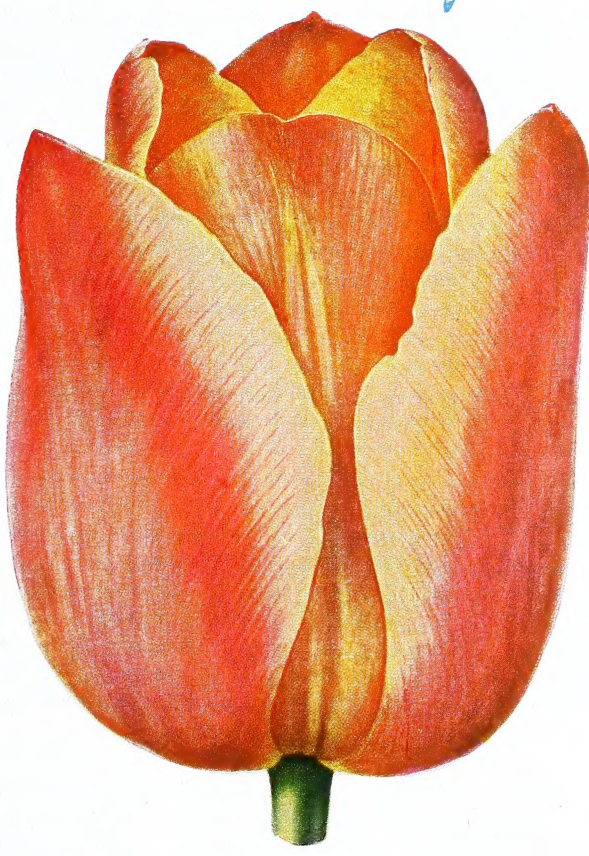

GOOD GRACIOUS

\section{DARWIN HYBRID TULIPS (Holland}

The Aristocrats of the Tulip World

Apeldoorn. Orange-scarlet; base black, edged yellow. Enormous flower. $\$ 1.30$ per doz,; $\$ 9.80$ per 100 .

Dardanelles. Sturdy, 20-inch stems carrying large, cherry-red blooms with yellow base. $\$ 1.30$ per doz.; $\$ 9.80$ рет 100 .

General Eisenhower. Very large flower of brilliant scarlet. $\$ 1.30$ per doz.; $\$ 9.80$ per 100.

Gudoshnik. Large, long petaled, yellow spotted red. Very Iarge flower. 3 for $50 \mathrm{c}$.; $\$ 1.80$ per doz.; $\$ 14.00$ per 100

Holland's Glory. Warm dazzling scarlet. Very large and exceptionally long lasting. $\$ 1.30$ per doz.; $\$ 9.80$ per 100 .

Red Matador. Bright fiery scarlet with vellow base shaded black. One of the most colorful of all garden Tulips; highly recommended. $\$ 1.25$ per doz.; $\$ 9.25$ per 100 .

Spring Song. Bright red flushed satin rose. Tall, strong stems. $\$ 1.25$ per doz.; $\$ 9.25$ per 100 .

Bulb-Tone, made with an organic base high in bone meal, is especially formulated for feeding bulbs, rhizomes, corms and tubers. Apply Bulb-Tone at the rate of $1 \mathrm{lb}$. per $25 \mathrm{ft}$. of tubers. Apply Bulb-Tone at the rate of
row. 2 Ibs. 69 c.; 5 lbs. $\$ 1.00 ; 10$ lbs. $\$ 1.75$

\section{BOLGIANO'S SPECIAL TULIP OFFERS}

Special Darewin Mixture

50 LARGE-SIZE BULBS $\begin{gathered}11 \text { to } 12 \mathrm{~cm} \text {. in } \\ \text { circumference }\end{gathered}$

All Colors Mixed \$3.25 Per bag of 50
Rainboun Collection of Darevin Tulips 100 LARGE-SIZE BULBS $\begin{aligned} & 111 / 2 \text { to } 121 / 2 \mathrm{~cm} \text { in circumference } \\ & \text { in }\end{aligned}$

Contains 10 each of 10 varieties. $\$ 7.50$ Per bag 


\section{MAY-FLOWERING TULIPS, continued}

William Pitt. Darwin. Very large, brillian carmine. \$1.25 per doz,; $\$ 9.25$ per 100 .

Zwanenburg. Darwin, Large;
$\$ 1.25$ per doz.; $\$ 9.25$ per 100 ,

May-flowering Mixture. Our own blend of top-size Holland Tulips. $\$ 1.25$ per doz, $\$ 9.25$ per 100

\section{May-flowering}

Double Tulips (Holland

AIso known as Peony-flowered Tulips, because the very full blooms resemble peonies in shape. Very satisfactory. Height 16 to 22 inches. Plant 5 to 6 inches deep; 6 inches apart.

Eros. Clear rose color; very large and double, $\$ 1.40$ per doz; ; $\$ 10.75$ per 100 .

Mount Tacoma. Semi-double; pure white. $\$ 1.40$ per doz.; $\$ 10.75$ per 100 .

Orange Triumph. Orange-red, flushed brown, with narrow yellow edge. $\$ 1.40$ per doz.; \$10.75 per 100 .

Symphonia. Immense; cerise-red. Strong Symphonia. Immense; cerise-red. St

Uncle Tom. Deep glossy red; large, peonylike. $\$ 1.40$ per doz.; $\$ 10.75$ per 100 .

\section{Double Early Tulips (Holland}

Ideal for bedding and garden borders. Easy to force indoors. Height 11 to 14 inches. Plant 4 to 5 inches deep, 5 inches apart.

All Gold. Pure buttercup-yellow; large flowers. Good forcer. 3 for $45 \mathrm{c}$.; \$1.75 per doz.; $\$ 13.75$ per 100

Electra. Deep cherry-red. Broad, satiny petals. Very showy and distinct. 3 for 45 c.; $\$ 1.75$ per doz.; $\$ 13.75$ per 100 .

Peach Blossom. Deep rosy pink; deepening with age to a deep rose. 3 for $45 \mathrm{c} ; \$ 1.75$ per doz.; $\$ 13.75$ per 100 .

Scarlet Cardinal. Brilliant scarlet-red, large flower. Early forcer. 3 for $45 \mathrm{c}$. $\$ 1.75$ per doz.; $\$ 13.75$ per 100.
choonoord. Pure white. Full (oz.; $\$ 13.75$ per 100

\section{Single Early Tulips $\begin{gathered}\text { (Holland } \\ \text { Grown }\end{gathered}$}

Excellent for early spring color Lono lasting; 10 to 14 -inch stems. Also easily forced indoors. Plant 4 to 5 inches deep. Bellona. Pure true yellow, long flower, verv fragrant, $\$ 1.50$ per doz; $\$ 11.50$ per 100.
Couleur Cardinal. Rich, glittering cardinal-red. $\$ 1.50$ per doz.; $\$ 11.50$ per 100.

De Wet (Fireglow). Golden yellow flushed orange. $\$ 1.50$ per doz,; $\$ 11.50$ per 100

Keizerskroon. Bright red with broad golden yellow border. $\$ 1.70$ per doz.; $\$ 13.00$ per

Pink Beauty. Deep rose with white flush outside. 3 for $50 \mathrm{c}$.; $\$ 1.90$ per doz.; $\$ 14.75$ per 100

White Hawk. Pure white. Fine for forcing and bedding. $\$ 1.50$ per doz.; $\$ 11.50$ per 100

\section{Tulip Species or Botanical Tulips (Holland}

These Tulips are particularly adapted for rock garden or borders. They show thei bright colors early in the season and have graceful recurving petals. For the most striking effects, plant in masses or clumps. Plant 4 inches deep, 5 inches apart except where noted. Bulb size varies from very small to $12 \mathrm{~cm}$. up, depending on the variety. Chrysantha. A fine low-growing medium early Tulip only 6 inches tall. Yellow with cherry on outside of petals. $85 \mathrm{c}$. per doz. $\$ 6.00$ per 100 .

Clusiana (Lady or Candystick Tulip). (French Grown.) Outer petals cherry-red, inner petals creamy white with violet base. Very choice for massing in front of evergreens. 8 in. $\$ 1.40$ per doz.; $\$ 10.50$ per 100. Kaufmanniana. One of the earliest va rieties, blooming early in April; colo creamy white tinged carmine. Plant 5 to 6 inches deep, 6 inches apart. Height 7 in. $\$ 1.40$ per doz.; $\$ 10.75$ per 100

Kaufmanniana Goudstuk. Brilliant green foliage, set off by an intense scarlet-red bloom with broad, butter-yellow edge. 3 for 70 c.; $\$ 2.65$ per doz.; $\$ 21.00$ per 100 .

Marjoletti. Pretty little flowers of creamy white flaked with pink. 18 in. $90 \mathrm{c}$. per doz.; \$6.50 per 100

Turkestanica. Five to nine flowers on one stem. Creamy white with green and bronzy flush on the outside. Lasts very well. 8 in. $\$ 1.30$ per doz; $\$ 9.75$ per 100 . White Emperor. Milky white flowers of remarkably large size. Long lasting and always fresh looking. Plant 5 to 6 inches deep, 6 inches apart. 3 for $80 \mathrm{c}$.; $\$ 3.00$ per doz.; \$23.75 per 100 .

\section{Parrot Tulips (Holland}

The petals are curiously fringed on the edges and they are very peculiarly marked and feathered. The form and coloring of the flower is especially attractive. We list only the choicest varieties. Plant 5 to 6 inches deep.

Black Parrot. A most exotic flower. This purple-black Parrot is unique, strikingly tall and beautiful. \$1.25 per doz.; \$9.25 per 100.

Blue Parrot. Waved petals, clear violetblue; very attractive $\$ 1.25$ per doz. $\$ 9.25$ per 100

Fantasy. A beautiful warm pink that delights everyone. An outstanding rare variety. $\$ 1.40$ per doz.; $\$ 10.75$ per 100 .

Orange Favorite. A magnificent deep rich orange throughout. $\$ 1.25$ per doz.; $\$ 9.25$ per 100.

Red Parrot. Raspberry-red. $\$ 1.40$ per doz.; $\$ 10.75$ per 100 .

Texas Gold. Very large; golden yellow. Petals deeply fringed. $\$ 1.25$ per doz.; $\$ 9.25$ per 100 .

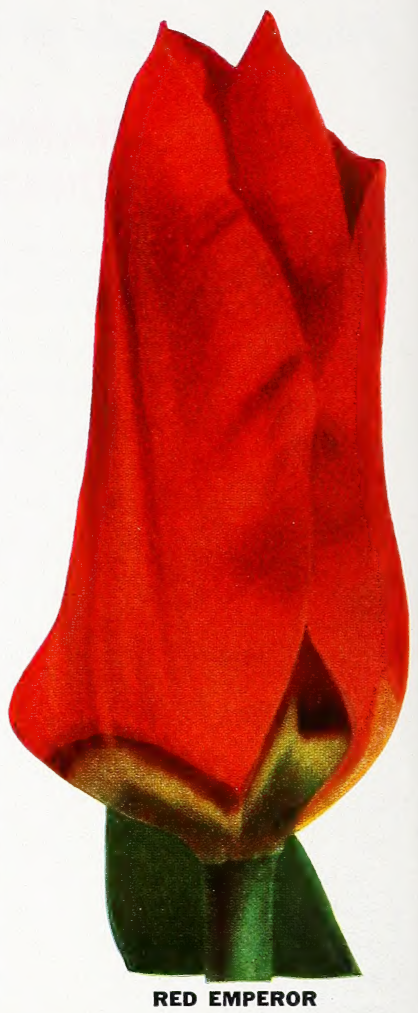

RED EMPEROR. So large and brilliant as to be almost unbelievable. The open blooms are up to 9 inches across! The color is dazzling vermilion-scarlet, with a black base bordered yellow. This is a spectacular Tulip that should be in every garden. 14 inches. Plant 5 to 6 inches deep, 6 inches apart. Top-size bulbs, $\$ 1.40$ per doz.; $\$ 10.75$ per 100 .

MAY-FLOWERING DOUBLE TULIPS

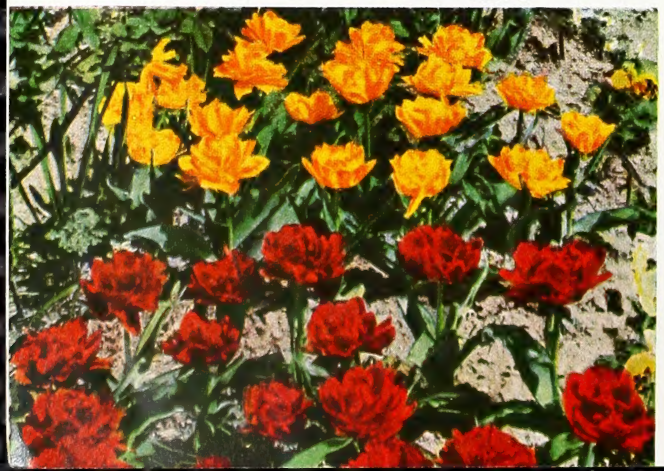

\section{4}

\section{GORGEOUS TRIUMPH TULIPS}

The Triumph class of Tulips blooms between the early and late varieties, on sturdy, 16 to 20 -inch stems. Be sure to see the pictures of each of these in color at either of our two stores.

Garden Party. Beautiful silvery white with very distinct and striking crimson-red edge. An outstanding variety of unusual merit. 3 for $50 \mathrm{c}$; ; $\$ 1.90$ per doz.; $\$ 14.75$ per 100

Olaf. A clear scarlet of most striking substance. An early variety of excellent form. $\$ 1.10$ per doz.; $\$ 8.25$ per 100 . United Europe. Glowing scarlet-red with slightly feathered ellow edge. A handsome combination of color. 3 for $40 \mathrm{c}$. $\$ 1.55$ per doz.; $\$ 12.00$ per 100

Willem Hopman. A truly magnifrcent Tulif, blush-purple edged silvery white, 3 for $50 c_{\text {; }} \$ 1.80$ per doz; $\$ 14.00$ per 100 


\section{Daffadile for BEAUTIFUL SPRING FLOWERS}

\section{Grown in the State of Washington}

No garden is complete without a liberal planting of Daffodils or Narcissus. Perfectly hardy, they grow and produce abundantly in almost any position, sun or shade, moist or dry. They are equally suited to pot-cuiture for winter flowering and are unsurpassed for naturalizing.

Note. The trumpet, crown, or cup is the center of the flower the perianth is the surrounding row of petals or wings. (EE) Extra Early; (E) Early; (M) Midseason; (L) Late.

All Daffodils listed are top quality, double nosed No. 1's unless otherwise noted. Prices quoted include delivery in the Washington, D. C. metropolitan area.

For Parcel post delivery charges, see page 2 .

Plant bulbs 6 inches deep, 6 inches apart except where noted

\section{Yellow Trumpet Daffodils}

Aerolite. A golden Daffodil that is replacing many of the present varieties. The large flower is beautifully proportioned, giving the impression of gracefulness despite its size. Primrose perianth, with a pure medium yellow trumpet, which is left in bold relief by the broad-pointed star formed by the flat opening outer petals. One of the longest lasting of all Daffodils opening outer petals. One of the longest lasting of all Daffodis
either in the garden or after cutting. (E) 3 for $50 \mathrm{c}$.; $\$ 1.85$ per doz.; $\$ 14.50$ per 100.

King Alfred. The most popular Daffodil in the world, and one that even today holds its own against all comers in every flower market. Because of its large size, golden yellow color and informal, pleasing shape it has become the universal faand informal, pleasing shape it has become the univers
vorite. (M) 3 for $50 \mathrm{c}$.; $\$ 1.75$ per doz.; $\$ 13.60$ per 100 .

Rembrandt. Golden yellow throughout. Broad, well-closed perianth; bold, elegantly recurved trumpet. Excellent for forcing. 3 for $55 \mathrm{c}$.; $\$ 2.10$ per doz.; $\$ 16.00$ per 100 .
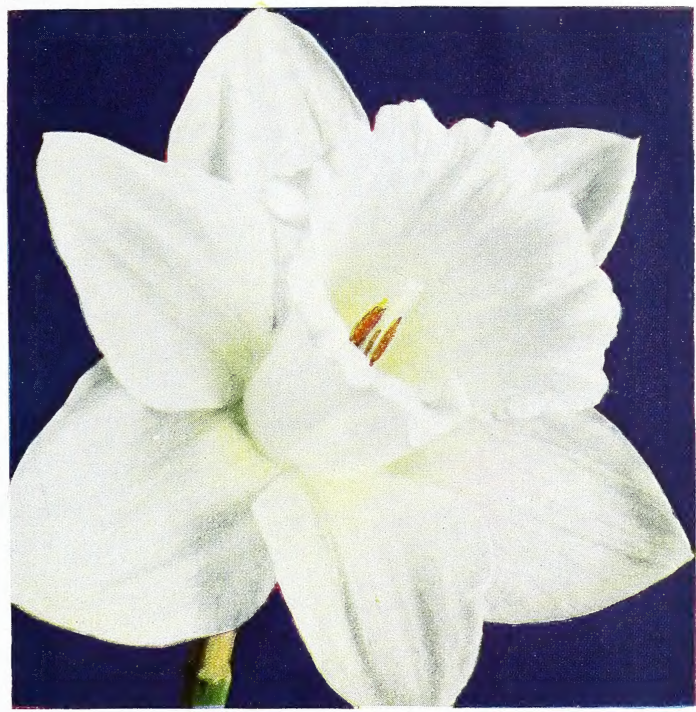

MOUNT HOOD

\section{Large Cupped Daffodils}

Dick Wellband. The perianth is pure white and the cup flame-orange. Its long-lasting quality and the startling contrast between perianth and cup makes it stand out in the largest collection of Daffodils. 3 for $45 \mathrm{c}$.; $\$ 1.65$ per doz.; $\$ 12.50$ per 100 .

Duke of Windsor. Broad, white, overlapping perianth. Large, pale yellow cup, very short and flaring. $50 \mathrm{c}$. each; 3 for $\$ 1.35$; 6 for $\$ 2.35 ; \$ 4.35$ per doz.

Fortune. Broad, creamy yellow perianth of very solid texture; these have glowing soft orange crowns of great size and elegant form, opening at mouth and frilled. (E) 3 for 45 c.; $\$ 1.70$ per doz.; $\$ 13.00$ per 100 .

Mrs. R. O. Backhouse. This is the famous "Pink Daffodil," Fine informal perianth of ivory-white, and well-proportioned, long slim trumpet of apricot-pink, changing to shell-pink at the deeply fringed edge. Dell-pink at the deeply fringed edge. substance; long lasting. A must for every garden. (E) 3 for $55 \mathrm{c}$; $\$ 2.10$ per doz.; $\$ 16.50$ per 100 .
LARGE CUPPED DAFFODILS, continued

Pink Supreme. A tall, vigorous grower. Overlapping, pure white perianth and large fluted deep pink cup, white at the base. (M) 3 for $70 c_{\text {. }} ; \$ 2.65$ per doz.; $\$ 21.00$ per 100

Red Bird. A large cup of fiery orangescarlet, in sharp contrast to the wellrounded, pure white perianth. A leading variety of the newer introductions. (I.) 3 for 50 c.; $\$ 1.75$ per doz.; $\$ 13.60$ per 100

Rustom Pasha. Large perianth of deep golden yellow, with rather long crown of deep solid orange-red. A large flower of intense color. (E) 3 for $50 \mathrm{c}$; $\$ 1.75$ per doz.; $\$ 13.60$ per 100 .

\section{Short Cupped Daffodils}

Mrs. Nette O'Melveny. A "little fairy" flower with pure white perianth and cup of clear lemon-yellow, with orange picotee. Splendid foliage, tall and graceful. In every way a delightful flower and sure to become immensely popular. (E) 3 for $45 c$. $\$ 1.60$ per doz.; $\$ 12.00$ per 100
SHORT CUPPED DAFFODILS, continued Magic Fire. Striking flower of excellent substance. Pure white, well-overlapping and broad perianth; small cup with fiery red rim One of finest exhibition varieties. (M) 3 for 45 c.; $\$ 1.60$ per doz ; $\$ 12.00$ per 100 .

\section{White Trumpet Daffodils}

Beersheba. A magnificent flower with large perfectly flat perianth; trumpet long and beautifully flanged at mouth. A flower of great size, measuring nearly 5 inches across. A vigorous grower and a grand exhibition variety. (M) 3 for $65 \mathrm{c}$.; $\$ 2.50$ per doz.; $\$ 20.00$ per 100

Mount Hood. An overlapping perianth of pure ivory-white, with a large, creamy white trumpet that changes to pure white when fully open. Heavily flanged at the trumpet mouth. (M) 3 for 65c.; $\$ 2.50$ per doz.; $\$ 20.00$ per 100 .

Mrs. E. H. Krelage. Uniform ivory-white in trumpet and perianth. Smooth, waxy texture and good form. (M) 3 for $50 \mathrm{c}$. $\$ 1.85$ per doz; $\$ 14.75$ per 100

\section{DICK WELLBAND}

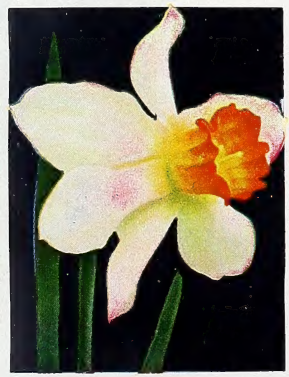

FORTUNE

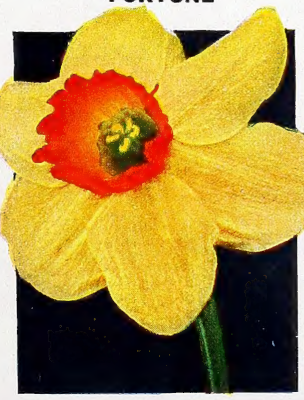

MRS. R. O. BACKHOUSE

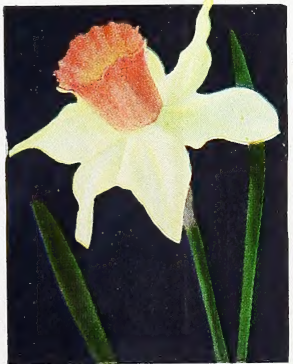

KING ALFRED

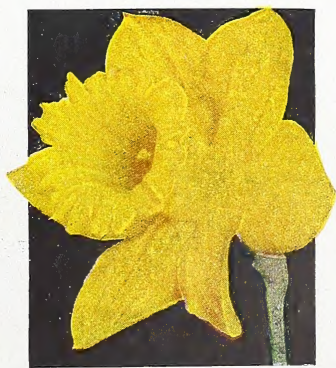




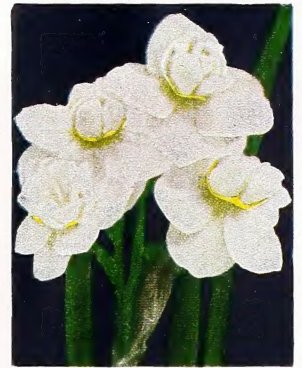

CHEERFULNESS

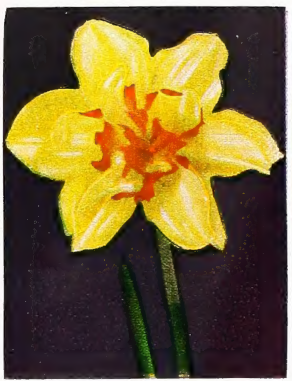

TWINK

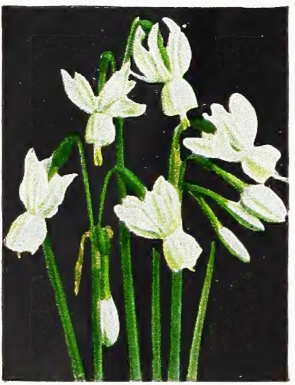

TRIANDRUS ALBUS

Cyclamineus Hybrids

February Gold. An extremely earlyblooming, small golden Daffodil with a rather star-shaped perianth. The trumpet is nicely fluted, straight, and shows a tinge of orange. A good forcing variety. 3 for $55 \mathrm{c}$; $\$ 2.00$ per doz.; $\$ 16.00$ per 100.

\section{Poeticus Types}

Actaea. The largest Poeticus in existence. Broad, snow-white perianth of great substance and good form; the very large eye is broadly margined with dark red. (E) 3 for $45 c$; $\$ 1.60$ per doz; $\$ 12.00$ per 100 .

White or Colored Shell Chips for planting Narcissus Bulbs. Lb. $15 \mathrm{c}$.; 10 lbs. $\$ 1.45$ (Not Postpaid).

Stone Pebbles for Planting Narcissus Bulbs. 3 lbs. 15c.; 10 lbs. 40c. (Not Postpaid).

\section{Double Narcissus}

Cheerfulness. A very pleasing double white Poetaz with good stems. A fine garden and show flower. (1)

Royal Sovereign. Valuable addition to the Twink group of semi-doubles. Most graceful of all in form, and the most charming, if not the most striking, in coloring. Creamy white interspersed with crinkled and frilled trumpet petals of primrose-yellow, shading to pale primrose as the flower develops. (M) 3 for $45 \mathrm{c}$. $\$ 1.65$ per doz.; $\$ 12.50$ per 100 .

Texas. A very large double pale yellow interspersed with brilliant orange. (M) 3 for $55 \mathrm{c}$. $\$ 2.00$ per doz.; $\$ 15.50$ per 100 .

Twink. A splendid show flower that has created much interest whenever exhibited. It is a double of the semi-full type, the petals alternating soft primrose and clear orange, and so arranged as to give the flower a most attractive appearance. Forces easily. Early, free flowering and hardy. (E) 3 for 45 c.; $\$ 1.70$ per doz.; $\$ 13.00$ per 100 .

\section{Triandrus Hybrids}

Triandrus Albus (Angel's Tears). One of the first heralds of spring. Several tiny, dainty white flowers are produced on each stem. $\$ 1.00$ per doz.; $\$ 7.50$ per 100.

Thalia. Beautiful clusters of two to three pure white flowers per stem. A lovely early variety, 3 for $55 \mathrm{c}$; $\$ 2.00$ per doz.; $\$ 16.00$ per 100

\section{Jonquilla Hybrids}

implex. The true single sweet Jonquil of light plext numerous small rich yellow flowers. Delicious scent. Plant 3 to 4 inches deep, 5 inches apart. per 100 .

Trevithian. The best of the short-crowned hybrid Jonquils. A fine, free-flowering variety, producing two or more pale lemon-yellow, sweet scented blossoms per stem. 3 for $45 \mathrm{c}$; $\$ 1.60$ per doz.; $\$ 12.00$ per 100 .

\section{Tazetta Types (Bunch Flowered)}

Geranium. One of the newer Dutch Tazetta hybrids with from five to seven large flowers per stem. The petals are rounded and overlapping; the short flat crown is orange-red. Outstanding in the garden and for exhibitions, and a gooc variety for late forcing. (L) 3 for $40 \mathrm{c}$.; $\$ 1.50$ per doz.; \$11.50 per 100 .
Miniature Daffodils No. 1 round bulbs

Bulbocodium Conspicuus. The Yellow Hoop Petticoat. Flowers rich golden yellow, of hooppetticoat form. Rush-like foliage. Height 6 inches. Blooms from the middle of February to early March and prefers a sandy peat soil with a fair amount of moisture while in growth, but not in summer: no manure should be given it. Plant 3 to 4 inches deep, 5 inches apart. (EE) $\$ 1.00$ per doz.; $\$ 7.50$ per 100 .

\section{Bulbs for Indoor Culture}

Paper-White Narcissus. Dishes of these, grown in pebbles and water, can be had in bloom continuously from Thanksgiving until Easter 3 for 50 c.; $\$ 1.80$ per doz.; $\$ 14.50$ per 100.

Grand Soleil d'Or. "Yellow Paper-White" with deep orange cup. Fragrant. Treat the same as the regular Paper-Whites, 3 for $75 \mathrm{c}$.; $\$ 2.85$ per doz.; \$23.00 per 100.

Chinese Sacred Lily. Flowers in clusters ver similar to those of the Paper-White Narcissus, 50 c.; $\$ 1.80$ per doz.; $\$ 14.00$ per 100 .

Hole-in-One Planter Bulb Planter and Plant Setter. This handy tool makes a hole in one operation. Merely cut the tool into the soil, re-

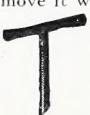
motion and the
soil comes with it,
leaving a clean
hole in which
bulbs or plants
may be set. $\$ 1.00$
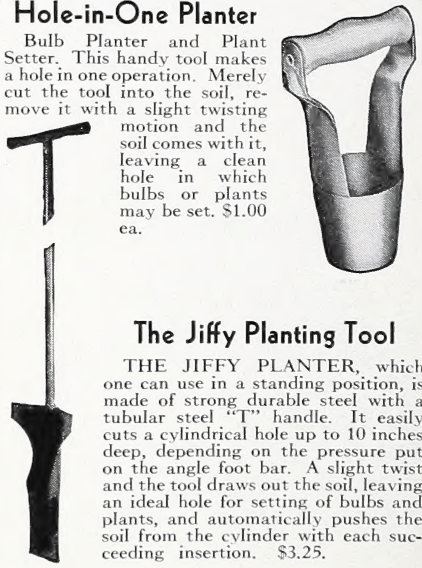

The Jiffy Planting Tool

THE JIFFY PLANTER, which ne can use in a standing position, is made of strong durable steel with tubular steel "T" handle. It easily cuts a cylindrical hole up to 10 inches deep, depending on the pressure put on the angle foot bar. A slight twist and the tool draws out the soil leavin ideal hole for setting of bulbs and plants, and automatically pushes the soil from the cylinder with each succeeding insertion. $\$ 3.25$.

\section{NARCISSUS FOR NATURALIZING}

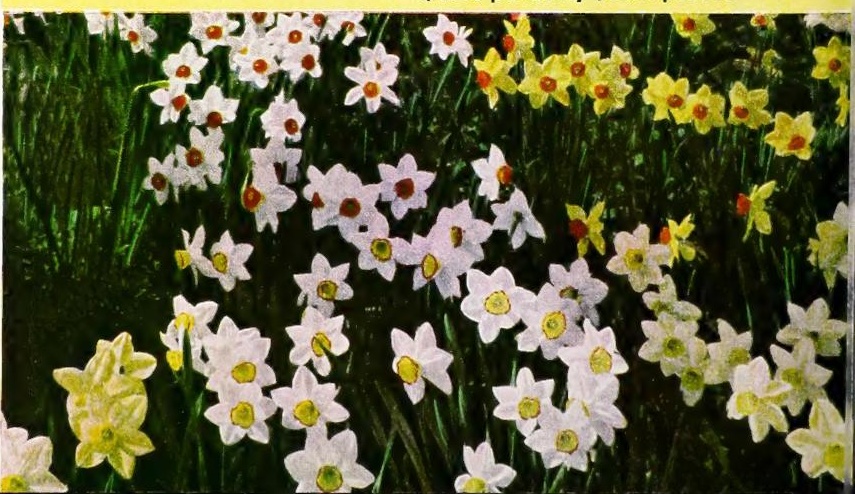

A mixture of No. 1 round bulbs, well assorted, in early and late varieties for naturalizing in masses or for mixed borders or among shrubbery. We recommend it strongly.

$\$ 1.20$ per doz.; $\$ 8.85$ per 100 


\section{Giant-Flowered HYACINTHS (Holland Grown)}

Each variety listed is available in two sizes: First-size bulbs produce real exhibition blooms when planted in beds out-of-doors or forced in pots indoors. Bedding-size bulbs will produce frne blooms when planted out-of-doors in beds and along borders. Plant bulbs 6 inches deep, 6 inches apart.

Large exhibition forcing size, 18 to $19 \mathrm{~cm}$. in circumference. 3 for $75 \mathrm{c}$; $\$ 2.75$ per doz.; $\$ 22.00$ per 100

Large bedding size, 15 to $16 \mathrm{~cm}$. in circumference. 3 for $50 \mathrm{c}$; $\$ 1.90$ per doz.; $\$ 15.00$ per 100

\section{Single Pure White}

L'Innocence. The very best white. A fine large truss of beautiful bells on a strong stem. Ideal for bedding and potting.

\section{Single Red and Pink}

Lady Derby. A pleasing shade of bright salmonpink. Bears a perfect truss of bloom on an erect stem.

La Victoire. Brilliant carmine-red. One of the very finest red varieties for bedding and forcing.

Marconi. Bright deep rose. Compact truss. Especially good for late forcing.

Single Dark and Light Blue

Amethyst. Beautiful light purple-violet.

Bismarck. A fine light blue variety, excellent for early forcing. Large, broad truss.

King of the Blues. Splendid spike of large bells of rich deep glossy blue. Good for bedding and late forcing.

\section{Single Yellow}

City of Haarlem. Beautiful Iarge, compact, creamy yellow bloom of fine form and substance.

\section{PLANTING}

FRENCH ROMAN HYACINTHS. Very early and easily grown. Each bulb produces three or four fragrant flower spikes. Excellent results come from planting three or four bulbs in a 5-inch pan. If potted in September, they will bloom about Christmas. White. 3 for $85 \mathrm{c}$,; $\$ 3.30$ per doz. Blue. 3 for 60 c.; $\$ 2.25$ per doz. Pink. 3 for 80 c.; $\$ 3.00$ per doz.
HYACINTH GLASSES $\rightarrow$ FOR GROWING HYACINTHS IN WATER BLUE. \$1.75 each CRYSTAL. $\$ 1.30$ each YELLOW. \$1.75 each RUBY. \$1.75 each Use exhibition size bulbs as listed above.

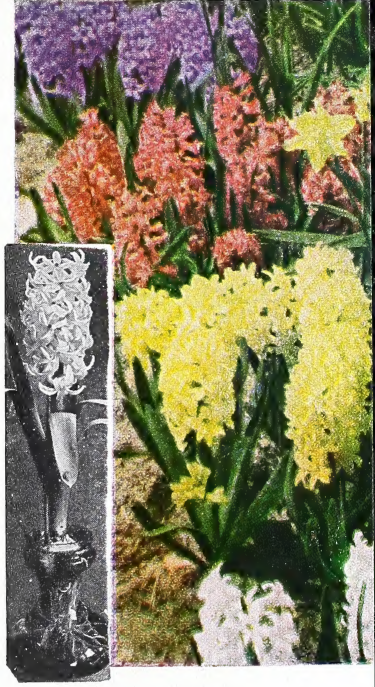

Bulbs
AMAR YLLIS, Giant American Hybrids. Amaryllis bulbs planted in October or November should come into bloom in March. Mixed colors only. Jumbo bulbs, suitable for planting in a 6 -inch pot, $80 \mathrm{c}$. each (by mail, $\$ 1.25$ ).

Separate Colors. (Holland grown.) Scarlet-red, Dark Red, White or Rose. Large bulbs, $\$ 3.40$ each; (by mail, $\$ 3.75$ ) extra-large bulbs, $\$ 4.95$ each (by mail, $\$ 5.35$ )

Hardy Amaryllis (Lycoris squamigera) (Domestic.) Strap-shaped leaves in spring, followed by clusters of pink lily-like blooms in August. Delightfully fragrant. Will grow in partial shade. 60c. each (by mail, 95c.).
ANEMONE (California Grown)

Blue Poppy. Violet-blue; black center His Excellency. Vivid scarlet with silvery white base and black center.

The Bride. Large, snow-white blooms.

Monarch De Caen, Mixed. Large, single flowers of blue, white and scarlet. Set

bulbs 5 inches deep in cool, moist but well-

drained soil. Spring is the best planting

time in the North, fall in the South.

St. Brigid. Double-flowered mixture. Any of above: $\$ 1.15$ per doz.; $\$ 8.50$ per 100

CHIONODOXA (Glory-of-the-Snow). (Holland grown.) Sky-blue flowers bloom soon after the snow is gone, $40 \mathrm{c}$, per doz. $\$ 3.00$ per 100 .

\section{CALLA LILIES (California Grown)}

Black (Arum pictum). Green spathe, deep purple inside. Large bulbs, 85c. each, 3 for $\$ 2.40$.

Pink (Zantedescbia Rebmanni). The blooms are not large but their beautiful pink color makes them very desirable and unusual Best for indoor culture. 60c. each; 3 for $\$ 1.65$.

White (Z. xtbiopica). Pure white. Pot bulbs in 6 to 8 -inch pots when received Large bulbs, 85c. each; 3 for $\$ 2.40$.

Yellow ( $Z$. Elliottiana). Large, rich deep golden flowers often 4 to 5 inches across at the mouth. Leaves spotted with white Ready in November. 65c. each: 3 for $\$ 1.80$

\section{CALla LiLies}

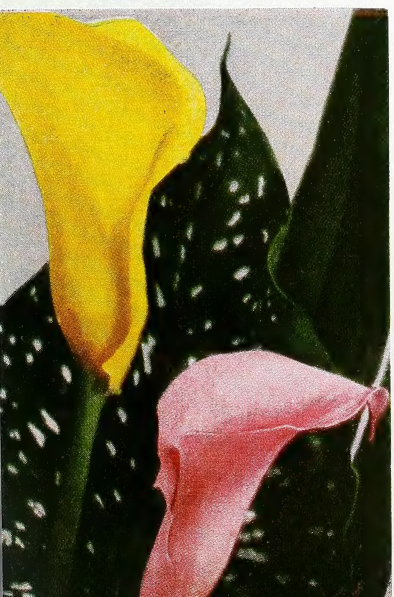

HARDY AMARYLLIS

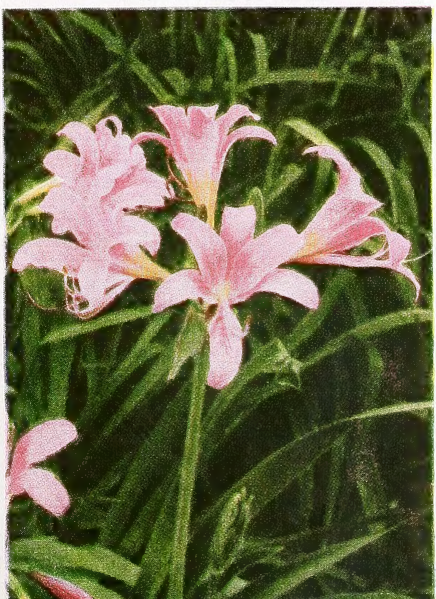

AMARYLLIS, Giant Hybrids

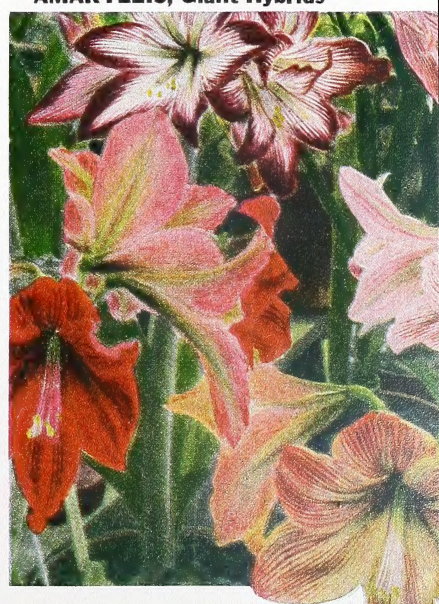




\section{HOLLAND CROCUS}

\section{Spring-Flowering}

Top-size bulbs, $9 \mathrm{~cm}$. and up in circumference

One of the earliest of flowers to bloom in the spring. Crocus will grow in the lawn, in flower borders, on the slopes of terraces. Plant inches deep.

Baron Von Brunow. Rich deep purple. $60 \mathrm{c}$. per doz.; \$4.25 per 100.

Remembrance. Dark blue. 60c. per doz.;

Kathleen Parlow. White. 60c. per doz.; $\$ 4.50$ per 100 .

Striped Beauty. 60c. per doz.; \$4.50 per 100 .

Yellow. 55c per doz; $\$ 3.75$ per 100 .

Special Crocus Mixture

Contains 100 large-size Crocus bulbs ( 8 to $9 \mathrm{~cm}$. in circumference) in mixed colors, packed in a lithographed bag.

SPECIAL PRICE, \$3.15 per 100

\section{SPECIES CROCUS}

Sieberi, Violet Queen. A pleasing light lilac-colored species type producing a 100 .

\section{Autumn-Flowering}

Plant Now-Bloom This Fall

Given a sheltered and sunny position in the rock garden, they add color at a time when most rock-garden plants are out of bloom.

Sativus (Saffron Crocus). Beautiful purple flowers feathered with white and adorned with bright orange anthers. $75 \mathrm{c}$. per doz.; 50 per 100

Speciosus. Iilac-blue flowers with contrasting orange-red anthers. 45c. per doz.;

Zonatus. Rosy lilac with a yellow center surrounded by a bright

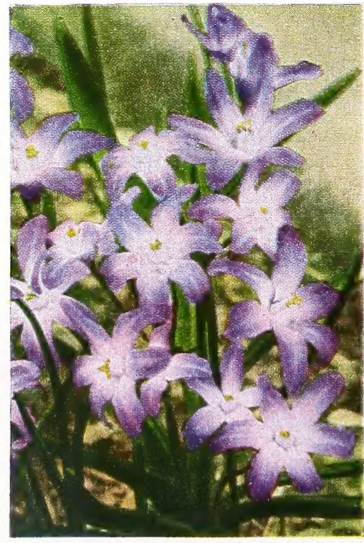

CHIONODOXA $\$ 4.25$ per 100 $\$ 3.00$ per 100

COLCHICUM autumnale major (Meadow Saffron). Autumn flowering. The rosy purple flowers resemble Crocus Planted in August or September, the bulbs will soon flower, but foliage will not appear until spring. Will bloom, without soil or water, in a sunny window. $65 \mathrm{c}$, each; 3 for $\$ 1.80$.

ERYTHRONIUM dens-canis purpureus (Trout Lily; Dogstooth Violet). Flowers like little stars in early April. Very hardy. 3 for $50 \mathrm{c}$; $\$ 1.75$ per doz.

FREESIA. Produces large sprays of very fragrant flowers. Plant the bulbs in a mixture of loam and coarse sand, with a little bonemeal.

White, Yellow, Lavender, Pink, Orange, Red or Mixed. 10c. each; $\$ 1.00$ per doz.; $\$ 7.50$ per 100.

FRITILLARIA meleagris (Snake's Head or Guinea-Hen Flower). Pendent, bellshaped flowers oddly marked and checkered. 10 to 18 inches high. $60 \mathrm{c}$. per doz.; $\$ 4.00$ per 100 .

DUTCH IRIS. One of the most easily grown bulbous plants. Place bulbs 4 to 6 inches deep in good sandy loam. Blooms in early June.

Imperator. Brilliant deep blue with a golden yellow blotch on each standard. 70 c, per doz, $\$ 5.00$ per 100

Golden Harvest. Both the standards and falls are bright golden yellow. $70 \mathrm{c}$. per doz.; $\$ 5.00$ per 100

King Mauve. Orchid-lavender, very large flower. 80c. per doz.; \$6.00 per 100. White Perfection. The finest white Dutch Iris in existence. $70 \mathrm{c}$. per doz.;
$\$ 5.00$ per 100 .

IRIS reticulata. Rich pansy-violet. Blooms in very early spring. About 10 inches tall. 65c. per doz.; $\$ 4.50$ per 100 .

Tingitana, Wedgwood. Graceful large flowers of a beautiful deep blue color.

IA (African Corn Lily) Brilliant mixture. 45c. per doz.; $\$ 3.00$ per 100

LEUCOJUM vernum (Spring Snowflake) Strong stems bearing large clusters of pendent white flowers tipped with green. 3 for $35 \mathrm{c} . ; 1.25$ per doz.

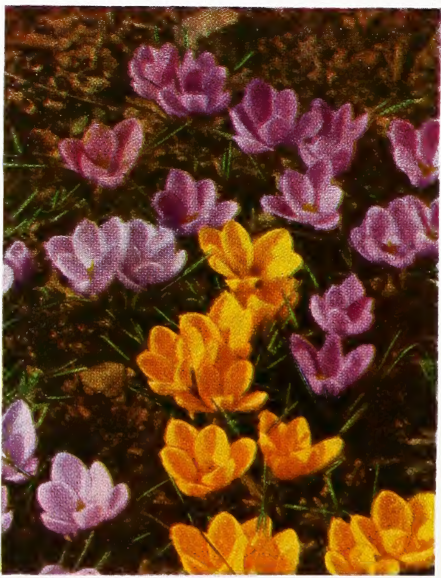

SPRING-FLOWERING

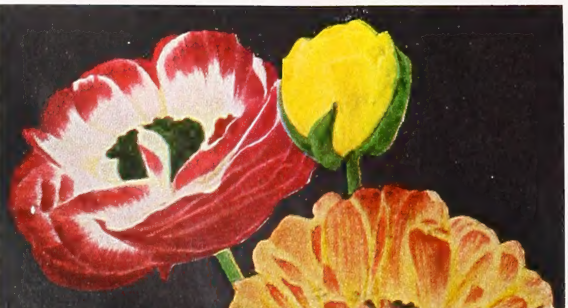
CROCUS

SCILLA $\longrightarrow$ CAMPANULATA

LYCORIS radiata. Bright red flowers in autumn. Plant indoors in the North. 3 for $40 \mathrm{c}$; $\$ 1.50$ per doz.

MUSCARI, Heavenly Blue (Grape Hyacinth). Numerous spikes of light blue flowers during April. Can be planted in masses or in the rock garden, in either shade or sun. 45c. per doz,; $\$ 3.00$ per 100 .

Botryoides album. Pure white Grade Hyacinth. 55c. per doz.; \$3.75 per 100

OXALIS. Suitable for pot-culture and winter blooming. Keep close to light to prevent foliage growing too long.

Bermuda Buttercup. Yellow.

Grand Duchess, Lavender.

Grand Duchess, White.

Boweii. Pink.

Each of above, 60c. per doz.; $\$ 4.50$ per 100 RANUNCULUS, Supreme Mixed. Large, turban-like heads of fully double flowers in a good range of color. Bulbs, 3 for , $\$ 1,50$ per doz.

SCILLA campanulata (Wood Hyacinth) Bears bell-like flowers on 15-inch spikes during early May.

Myosotis. Blue. 60c. per doz.; $\$ 4.50$ per

Queen of the Pinks. $60 \mathrm{c}$. per doz.; $\$ 4.50$ per 100.

White Triumphator. 60c. per doz.; $\$ 4.50$ per 100 .

SCILlA sibirica, Spring Beauty. Exquisite rich blue flowers in early spring. 85c. per doz.; $\$ 6.00$ per 100

SNOWDROPS. May be used effectively in the center or at the edge of a bed.

Single. Large, lovely single white bells. 75c. per doz.; \$5.50 per 100.

Double. Same as the single, but large, double flowers. \$1.00 per doz.; \$7.25 per 100.

SPARAXIS. Similar to Freesias, but much hardier and in a wide range of color 100

STERNBERGIA lutea. Gorgeous yellow Blooms same time as Colchicum and is similar in growth. 3 for $70 \mathrm{c}$.; $\$ 2.50$ per do

WINTER ACONITE (Erantbis buemalis) Golden blossoms look charming resting on an emerald-green cushion of leaves. Does well in a moist situation, such as
under trees. 55 c. per doz.; $\$ 3.85$ per 100 .

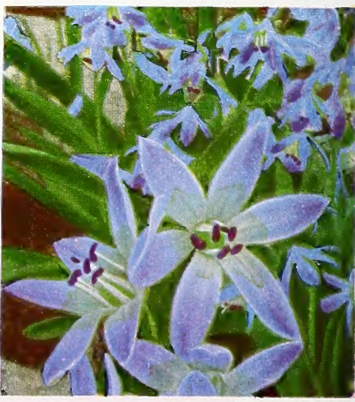

SCILLA SIBIRICA, Spring Beauty

RANUNCULUS

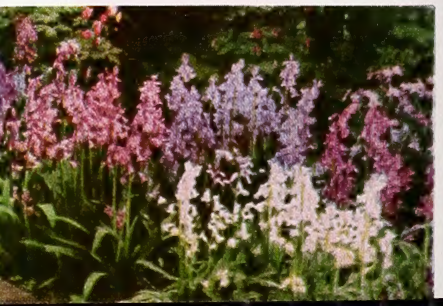




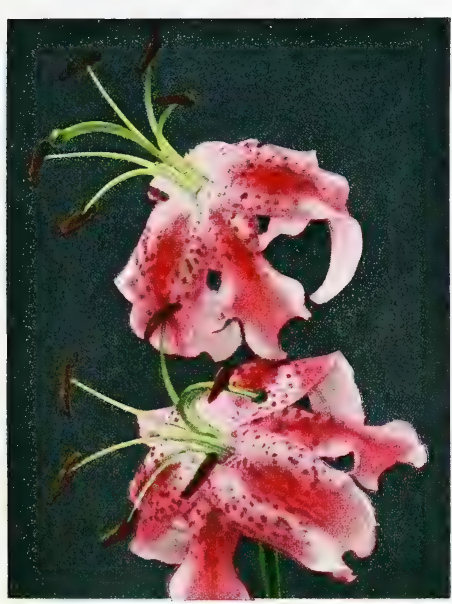

SPECIOSUM RUBRUM

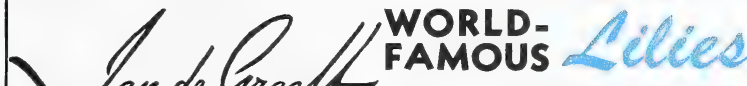 ande \\ Exotic-Colorful-Easy to Grow}

These glorious Lilies were grown for you in Oregon on the slopes of lovely Mount

Hood. Your order will be shipped direct to you, beginning in October. Each 30

Cinnabar. Finest vivid maroon-red. An upright-flowering Mid-Century

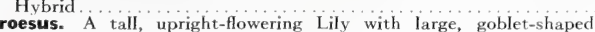

Croesus. A tall, upright-flowering Lily with large, goblet-shaped,
golden yellow flowers nicely marked with nearly black spots. 3 to 4 ft. tall. Flowers in late June

Emerald Strain. Pure cool white

Enchantment. Vivid nasturtium-red

Golden Clarion Strain. Dependable, vigorous golden flowers. Will

thrive wherever Regale Lilies can be grown.

Jillian Wallace. Carmine-red with white margin, spotted deep crimson. $400 \quad 1100$

Moonlight Strain. Chartreuse-green and apple-vellow-green........ 2507700

Olympic Hybrids. Soft cream-fuchsia-pink through icy-green ...... $75 \quad 200$

Pink Perfection Strain. Flowers are suffused a deep fuchsia-pink

over the innner as well as the outer surface of the petals

$200 \quad 550$

Speciosum Red Champion. A grand Lily for garden decoration, cut

flowers or pot culture in a cool greenhouse. Intensely rich, pink-

spotted crimson red.

$100 \quad 250$

Madonna (Lilium candidum). White. June blooming. French grown. 60c. each; 3 for $\$ 1.70 ; \$ 6,50$ per doz.
Regale. White with a shading of lilac-pink on outside; sweet scented. $75 \mathrm{c}$, each Regale. White with a shadi
3 for $\$ 2.00 ; \$ 7.50$ per doz.

Speciosum Rubrum. White, tinted pink and heavily spotted red. 95c. each; 3 for

$\$ 2.70 ; \$ 10.00$ per doz.
Croftii. Write for prices.

\section{HUFFY VACUUM \\ LEAF CLEANER}

As easy and efficient as a vacuumcleaner. Many times

faster than raking leaves. Cleans 31 inches at a time. The self-discharging bag saves time and effort. Compact and sturdy. $\$ 154.50$.

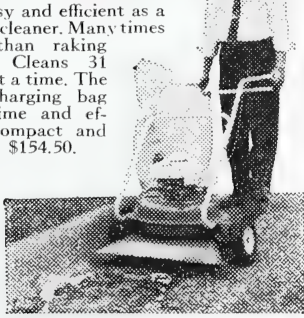

Gold Tag Bone Meal. For bulb gardens, lawns and flowers. 100 Ibs. $\$ 6.95$

compo. Turns compost into organic

Compo.
manure. $71 / 2$ Ibs. $\$ 1.25 ; 25$ lbs. $\$ 2.50$.

Premier Brand Peat Moss. Large $7 \mathrm{cu} . \mathrm{ft}$ bale $\$ 5.45$.

Doom. Milky disease spore dust. Controls Japanese beetles in the soil. 10 ozs. $\$ 3.75$; 20 ozs. $\$ 7.45$.

Wizard Brand Sheep Manure; also Wizard Brand Cow Manure. Either, 25 Ibs. $\$ 1.75 ; 50$ Ibs. $\$ 2.95 ; 100$ Ibs. $\$ 5.75$. Bovung Cow Manure. 25 lbs. $\$ 1.75 ; 50$ Ibs. \$2.95; 100 Ibs. \$5.75.

\section{ROSS ROOT FEEDERS The Key to Outdoor Beauty}

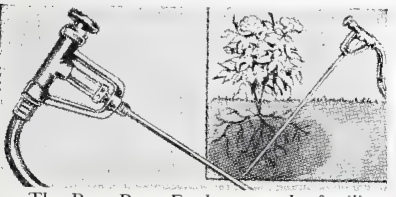

The Ross Root Feeder puts the fertilizer and water directly to the roots. Especially fine for roses, shrubs and trees. $\$ 6.98$ complete with 12 cartridges. Additional cartridges, $\$ 1.00$ per doz.

Iron Cartridges. $\$ 1.50$ per doz.

Weedone Weed Killer. Contains the powerful 2,4,5-T and 2,4-D, the two most ozs. $\$ 1.00$; pt. $\$ 1.69$; qt. $\$ 2.75$; gal. $\$ 6.75$.
Dow Crab Grass Killer with Zytron

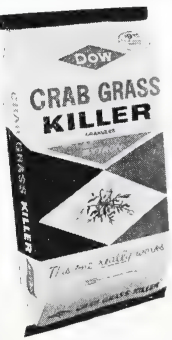

No need now to
dig crabgrass by
hand. Apply Dow
Crab Grass Killer
just once and be
worry-free for the
entire season. Stops
crabgrass before it
ever starts. Apply
on established lawns
in fall or early spring.
Contains no mer-
cury, or arsenics;
won't harm children,
pets or birds.
Dow Crab. Grass
Killer comes in dry
form for spreader
application. 20 Ibs.
covers 2500 sq. ft.
$\$ 8.95$.

RA-PID-GRO 23-21-17

RA-PID-GRO contains many elements and trace elements which plants require in order to produce good growth. RA-PIDGRO supplies them in very small amounts, so it should be fed regularly during the growing season. 6 ozs. $50 \mathrm{c}$; 8 ozs. $75 \mathrm{c}$.; Ib. $\$ 1.30$; 2 ibs. $\$ 2.50 ; 5$ lbs. $\$ 4.75 ; 10$ Ibs. $\$ 9.00 ; 25$ lbs $\$ 22.50$.

\section{BACCTO MICHIGAN PEAT}

An outstanding soil conditioner and mulch for lawns and planting of flowers and nursery stock. 1/2pk. 59c.; pk. 98c.; 25 Ibs. \$1.59; 50 Ibs. $\$ 2.29 ; 100$ Ibs, $\$ 3.98$.

\section{REDWOOD PLANT TUBS}

Made of the finest redwood, for long life. Octagon - shaped,

with recessed brass

bands.

$10 \mathrm{in.}$

12 in.

14 in

16 in

$\$ 260$

380

498

$\begin{array}{ll}6 & 25 \\ 8 & 35\end{array}$

Coastersfor Redwood Tubs. 12 in. (for 10 to 14 -
in. tubs) $\$ 4.35 .14$ in. (for 16 to 18 -in. tubs) $\$ 5.50$

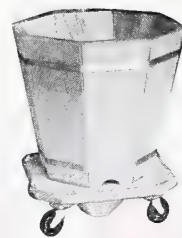

\section{WILT-PRUF}

Spray on choice plants and evergreens It forms a colorless film which retards winds. 8 ozs. $\$ 1.49$; qt. $\$ 3.50$; gal. $\$ 10.75$.

\section{SPREADERS}

For Fertilizer, Lime or Seed

These rugged and dependable Spreaders are made of heavy gauge material with finger-tip control. The agitator distributes fertilizer or seeds in correct amounts, accurateIy regulated by the feeder slide. Each machine pays its own way because it distributes fertilizer and other materials evenly and in the proper amount.

Salem. 18 in. Micro-Se

Salem. 23 in. Micro-Set.

Salem. $28 \mathrm{in}$ Micro-Set.

Modern. 17 in.

Modern. 20 in.

Modern. 24 in.

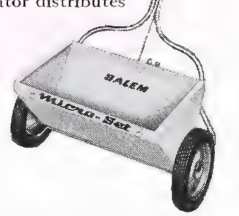

Cyclone. Spreads 48 in

$\$ 1645$ $\begin{array}{ll}22 & 45 \\ 28 & 45\end{array}$

\section{SPIKE DISC AERATOR}

Will supply the proper kind of aeration and permit retention of moisture. Also useful before reseeding and top dressing. Seed and fertilizer reach into the $k$ nife-like cuts in the turf, safe from wind and rain. No. 8. $\$ 21.00$.

\section{PERMA MULCH}

Ground pine bark - Nature's way of mulching. Economical to use, retains moisture, does not wash away and assures better aeration of the soil. $3 \mathrm{cu}$. ft. $\$ 2.69$.

\section{DELUXE SOIL AERATING TOOL}

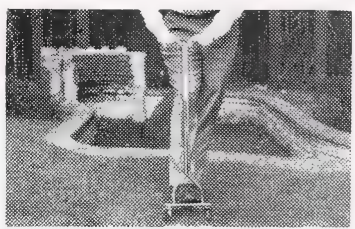

De Luxe. Double tine for Iawns. Tubular steel; chrome plated. Overall length 36 inches. \$6.95 each. 


\section{Peanies __}

\section{SINGLE PEONIES}

Ecstasy. Exceedingly beautiful. Lovely satiny pink, lighted up by a Eva. Brilliant coral-pink with yellow center. An unusual and attrac-

King of England. Deep carmine. \$1.50 each.

L'Etincelante. Brilliant yet soft velvety carmine with a silver margin. Strong stems. Early. \$2.00 each.

Mikado. Deep crimson; staminodes dark rose-red with golden edges. Mr. G. F. Hemerik. Enormous, deep pink flower with two rows of

Snow Wheel. An outstanding variety. Large, well-formed flowers on stiff stems. Free-blooming, compact plant growth. The best
single white for show in the garden and for cutting. The large, distinctive yellow center adds to its beauty $\$ 2.50$ each.

\section{SPECIAL! You may pick one each of any 3 of the above} varieties for $\$ 5.00$; or any 6 for $\$ 9.00$

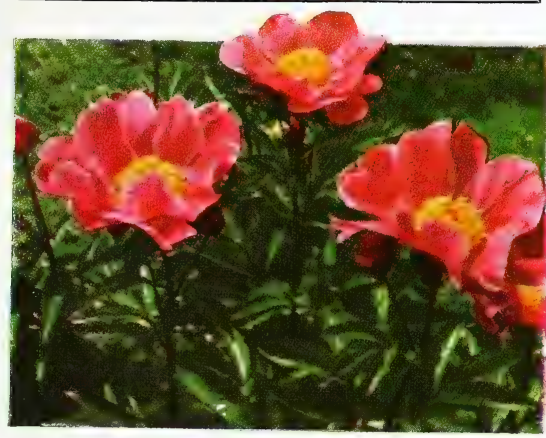

SINGLE PEONY L'ETINCELANTE

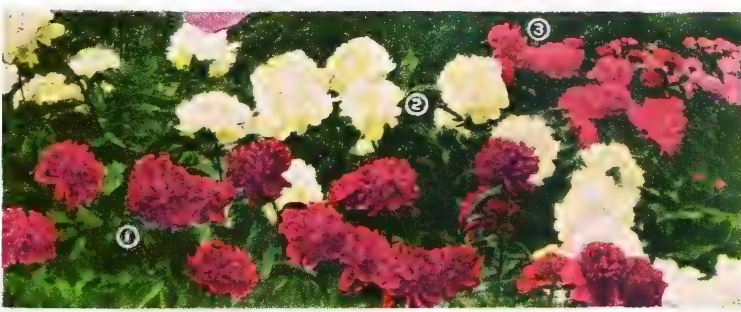

1. INSPECTEUR LAVERGNE 2. BARONESS SCHROEDER 3. JEANNOT

\section{DOUBLE PEONIES}

The number following the name means the rating of the American Peony Society. (E) indicates earliest flowering varieties; (E-M) early

Baroness Schroeder. 9.0 (M) Blush, turning to purest white; fragrant. $\$ 1.25$ cach; Cornelia Shaylor. 9.1 (L) Shell-pink. Fine-shaped flower, Outstanding. \$1.75 each; E. C. Shaw. 9.1 (M-L) Light old-rose; very fragrant. $\$ 2.50$ each; 3 for $\$ 6.50$ Festiva Maxima. 9.3 (E) Fine white, with few crimson flecks. $\$ 1.25$ each; 3 for $\$ 3.25$ 12 for $\$ 12.00$.

Inspecteur Lavergne. 8.7 (E) Beautiful deep red. $\$ 1.50$ each; 3 for $\$ 4.00$ Jeannot. 9.2 (L) Light lavender-pink; very sweetly rose scented. $\$ 1.50$ each; 3 for $\$ 4.00$. Karl Rosenfield. 8.8 (M) Bright crimson. Free bloomer. One of the best deep reds Lady Alexandra Duff. 9.1 (E-M) Light pink, fading to white, touched with yellow and carmine. $\$ 1.50$ each; 3 for $\$ 4.00$.
Le Cygne. 9.9 (E) Finest pure white. The highest rated Peony, $\$ 2.50$ each: 3 for $\$ 6.50$ Miss Eckart. 8.1 (L) Very large. Deep pink on sturdy stems. \$2.00 each; 3 for \$5.25. Mons. Jules Elie. (E) Immense flower of fine pink. One of the best pinks for cutting. Mons. Martin Cahuzac. 8.8 (E-M) Dark maroon-red. The darkest Peony. \$2.25

Mrs. Edward Harding. 9.3 (M) Pure white, golden stamens. $\$ 1.50$ each; 3 for $\$ 4.00$. Primevere. 8.6 (M) Light creamy yellow. \$1.75 each; 3 for $\$ 4.75$. Richard Carvel. 8.8 (M) Brilliant crimson. $\$ 1.50$ each; 3 for $\$ 4.00$. Sarah Bernhardt. 9.0 (L) Deep rose-pink, silver tippe
late cut flower. $\$ 1.50$ each; 3 for $\$ 4.00 ; 12$ for $\$ 12.50$.

Therese. 9.8 (E-M) Very large, pale, translucent old-rose-pink, paling toward the base. Walter Faxon. 9.3 (M) Vivid shell-pink of luminous intensity. $\$ 2.00$ each; 3 for $\$ 5.25$.

COLLECTION F62-1 3 Peonies Pictured above Baroness Schroeder Jeannot Inspecteur Lavergne ALL THREE for only

Space does not permit us listing all the varieties of Iris we have available. Write or phone us for prices
on any variety you may desire.
Accent. 36 in. Large clean yellow standards contrast most pleasantly with the rose-red falis. A noteworth
\$1.00 each.

Apricot Glory. 36 in. Apricot pink with a self colored beard and a slightly deeper coloring the hafts. \$1.00 each.

Arabi Pasha. 36 in. Rich cornflower blue. The coloring is accented by a blue beard. $\$ 1.50$ each. Argus Pheasant. 36 in. Large flowers with broad, flaring falls and wide standards. A smooth, bright gol

Ballet Dancer. 37 in. A delightful golden apricottan self with flaring form symbolizing the swir ing skirts of the ballet dancer. 75c. each.

Bazaar. 36 in. Colorful as a Tunisian bazaar is this glorified version of Raspberry Ribbon with its broad falls and leathery substance. A free blooming wine-colored plicata, \$1.50 each.

Black Diamond. 38 in. This ebony-blue-black glistens with a lustrous black-silk sheen. Not as
tall as some, but flowers are good size. 75 c. each. tall as some, but flowers are good size. $75 \mathrm{c}$. each.
Black Hills. 38 in. A very tall, ebony-black Iris with lots of bloom, widely spaced on the stem. Thise who have grown Black Forest will find this variety

Blue Sapphire. 40 in. Large, ruffled, light blue. Dykes Medal, 1958 in. Large,

Cloud Cap. 40 in. Largest of all the tangerinebearded, shell pinks. \$1.00 each.

color is a dee heavy markings of vivid purple on the falls. $\$ 1.00$ eac

Copper Medallion. 38 in. Large, full blossoms have the glitter and sparkle of a newly minted penny. We think this var

Desert Song. 38 in. A bright creamy lemon yellow. The flowers are ruffled, large and flaring.

Elmohr. 40 in. Rich red-mulberry. One of the largest of all. $\$ 1.00$ each Firecracker. 35 in. Brilliant dark burgundy-red
marked plicata with a yellow trim. $75 \mathrm{c}$. each.
Frost and Flame. 44 in. Largest and best of all Golden Russet. 38 in A beautiful Iris which the name well describes. $\$ 1.00$ autiful

Golden Sunshine. Outstanding clear soft yellow. Golden Sunshine. Outstanding clear soft vell

Happy Birthday. 36 in. This new pink of good The is exquisitely ruffled and of fine substance.
The color is a rich, clear pink, deeper than Cherie

Helen Collingwood. $38 \mathrm{in.}$ A large amoena-type flower. The standards are white, tinted blue; and flower. The standards are white, tinted

Her Grace. A very beautiful and fascinating Iris. Her Grace. A very beautiful and fascinating

June Bride. $30 \mathrm{in.}$ Deep flamingo-pink with an odd buff-apricot undertone. Lovely flaring form. each.

Lavanesque. $40 \mathrm{in.}$ An orchid-pink, lacily frilled Hower. $\$ 1.50$ each.

Mary Randall. 36 in. A smooth self of rich deep orchid or bengal-rose with a full tangerine bearc

New Snow. 38 in. White as new snow. Large, ruffled, flaring falls and full, bright yellow bear. No haft markings. Delightfully crisp. One of the very best whites, $75 \mathrm{c}$, each

Pacemaker. 36 in. Smooth, velvety red self. One of the best reds. Glossy sheen and good size. $\$ 1.00 \mathrm{cach}$

Palomino. 36 in. A distinct new color combination. The standards are soft ivory with a light pink infusion, and the falls are pale ivory with a border of copper amber which widens at the haft
to nearly touch the fiery red beard. $\$ 1.00$ each. to nearly touch the frery red beard. $\$ 1.00$ each.
Party Dress. 34 in. A medium size pink of fine Party Dress. 34 in. A medium size pink of fin form with

Pierre Menard. A magnificent rich blue. The slightly open standards are hyacinth-blue, the falls campanula-violet, with a canary-yellow beard as an effective foil. Rich deep blue, one of the finest. $\$ 1.00$ each Pink Formal. 38 in. A large, somewhat ruffled
rich pink. $\$ 1.00$ each.
Pink Sensation. 36 in. True delicate light pink and sporting the famous tangerine or orange-red beard. Large flower. $75 \mathrm{c}$, each: 3 for $\$ 2.00$. Trimrose-yellow clear white, Pretender. $35 \mathrm{in.}$ Yellow and violet, a beautiful Rainbow Room. 36 in. A handsome blend of yellow and all the rainbow colors. Accented with Ranger. 36 in. Deep near crimson-red self Bronze-orange beard on browning haft. A fine Sable Night. 38 in. A sensational new black Iris. The flowers are large and full petaled with very heavy substance and a smooth finish. The
smooth darkcoloring is slightly undertoned purple-

Solid Gold. 38 in. Beautiful rich deep yellow self The flowers are large and ideally formed. $75 \mathrm{c}$. Starshine. $38 \mathrm{in.}$ A real beauty and very popular. are blue-white edged cream. 75c. each. Sunset Blaze. $40 \mathrm{in.}$ Golden flame-salmon blend is almost a red except for the gold influence that Sunset Serenade. Unique golden apricot. $\$ 1.00$ Tabu. 38 in. An ebony-blue-black self; even the Tabu. 38 in. An ebony-blue-black self; even the
beard is virtually black. Petals are glossy and Shine in the sun. $\$ 1.00$ each. peachy undertone. The blooms are extra large. the falls flaring way out and then drooping

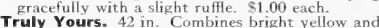
light cream colors, with both standards and falls vatican Purple. 36 in. Deep but bright bluein finish and heavy in texture. $\$ 1.00$ each

Velvet Dusk. 36 in. A descendant of Sable and carries its black-violet tones with a rich glisten.
The good-sized flowers are on well-branched stems. The bloom is full, well flared and rounded. $\$ 1.00$ each. 


\section{BOLGIANO'S Newest and Best ROSES for your Garden}

\section{All-America Winners for 1963}

ROYAL HIGHNESS. Hybrid Tea. Plant Pat. 2032. Soft pink blooms on a well-branched plant. A beautiful rose both in bud and in full bloom. Fragrant, too. $\$ 3.50$ each; 3 for $\$ 9.20$.

TROPICANA. Hybrid Tea. Plant Pat. 1969. A brilliant new color, glowing orange-red. Five-inch blooms that never lose their color. Wonderful as cut flowers. $\$ 3.50$ each; 3 for $\$ 9.20$.

\section{SPECIAL COLLECTION F62-14 \\ Royal Highness \\ All-America Winners \\ Tropicana \\ $\$ 6.35$}

TROPICANA

\section{ROYAL $\rightarrow$ \\ HIGHNESS}

\section{All-America Winners for 1962}

\section{CHRISTIAN DIOR. Hybrid Tea. Plant Pat. 1943. A glorious} color-bright red, clear and sparkling. The bud is pointed and Long stems. Light fragrance. Glossy, leathery foliage on a \$ $\$ 3.50$ each; 3 for $\$ 9.20$

GOLDEN SLIPPERS. Floribunda. Plant Pat. App. For. A most attractive combination of colors. Buds are red, orange color. The new foliage is tipped bronzy too. A compact grower about 2 feet tall. $\$ 2.50$ each: 3 for $\$ 6.60$.

JOHN S. ARMSTRONG. Grandiflora. Plant Pat. 2056. A long-lasting, dark velvety red flower of very pleasing form, borne singly and in clusters. The plant is of good proportions,
4 to 5 feet tall. A descendant of Charlotte Armstrong. $\$ 3.50$ each; 3 for $\$ 9.20$.

Harid Tea. Plant Pat 2103. This huge aled and high pointed, is clear golden yellow. It oth in clusters and on individual stems. Strong, tall plant that blooms profusely. $\$ 3.50$ each; 3 for $\$ 9.20$

\section{HYBRID TEA ROSES}

Blanche Mallerin. Plant Pat. 594. Outstanding

Careless Love. Plant Pat. 1582. Red streaked Chicago Peace. Plant Pat. 2037. Pink with yelChrysler Imperial. Plant Pat. 1167. Vivid

Condesa de Sastago. Scarlet and yellow. $\$ 1.50 \mathrm{ea}$ Crimson Glory. Deep crimson-red. $\$ 1.50$ eact. Duet. Plant Pat. 1903. Soft salmon-pink with ric Garden Party. Plant Pat, 1814. Cream and ivory, tinted sofink. Large, fully double, Vigorou Hawaii.

Helen Traubel. P P . 1028 on

K. A. Viktoria. Cream-white; fragrant. $\$ 1.50 \mathrm{ea}$ Kordes Perfecta. Plant Pat. 160t. Cream-white, cidged carmine. $\$ 3.00$ each; 3 for $\$ 7.95$. $\$ 1.50 \mathrm{ca}$ orange, $\$ 2.75$ Nocturne. Plant Pat. 713. Rich red with enticing Paramount. Plant Pat. 984. Fragrant orangePeace. Favorite yellow Rose. $\$ 1.95$ each. Pink Peace. Plant Pat, 1759. Deep dusty pink. President Herbert Hoover. Two-tone rose and Radiance. Popular pink. $\$ 1.50$ each.
Red Radiance. Rosered. $\$ 150$ cach. Suspense. Plant Pat. 1944. Rich red petals with Sutter's Gold.

Tiffany.

White Knight

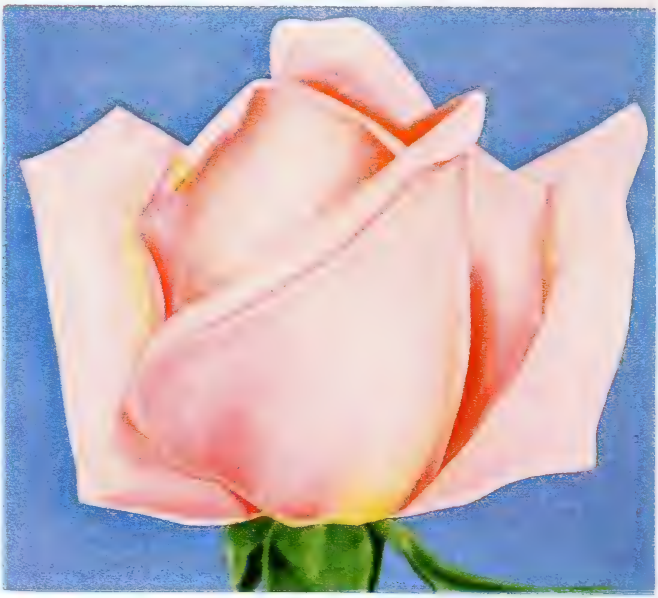

NEW GRANDIFLORAS Golden Girl. Plant Pat. 1912. Double, highcentered flowers of sparkling golden yellow sturdy plant of bushy habit, blooming very freely. Montezuma. Plant Pat. 1383. Long slender buds and large blooms of a rosy salmon color. A good cutting Rose with long stens. 22 Mt. Shasta. Plant Pat. 2132. New white GrandiQueen Elizabeth. Plant Pat. 1259. Betutifu! plant. Ruffled petals. $\$ 2.50$ each; 3 for $\$ 6.60$. Starfire. Plant Pat. 1742. Non-fading currantsingly and in clusters. Tall plant with glossy

\section{FLORIBUNDA ROSES} circus Fashion. Plant Pat. 789. Coral-pink suffused Fire King. Plant Pat. 1758. A tall plant. Double, Garnette. Garnet-red "sweetheart" flowers. Gold Cup. Plant Pat. 1683. Deep yellow. \$2.00 Lavender Girl. Plant Pat. 1672. Rnsy lavender, Red Pinocchio. Plant Pat. 812. Rich carmine. Spartan. Plant Pat. 1357. Orange-red, changing

\section{CLIMBING ROSES}

Blaze, Improved. Huge clusters of vivid scarlet.

Coral Dawn. Plant Pat. 1117. A very good everclimbing Crimson Glory. Plant Pat. 736. Deep Golden Showers.

\section{FINE COLLECTIONS}

4 All-America Roses for 1962 John S. Armstrong King's Ransom
Golden Slippers COLLECTION F62-15

1 each of the above 4 All-America $\$ 11.40$ 4 HYBRID TEAS

Garden Party Duet Kordes Perfecta Pink Peace COLLECTION F62-9

1 of each for .......... \$10.60

THE FLORIBUNDA GROUP Gold Cup Fire King Circus Spartan

1 of each for. $\$ 7.90$ 


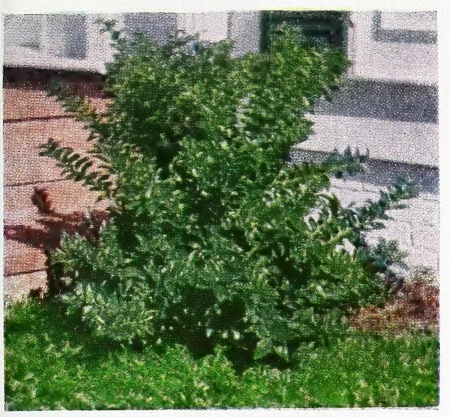

PRIVET LUCIDUM

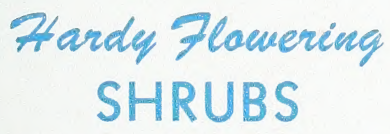

ALMOND, Flowering. Double-pink flowers in early spring. 18 to 24 in., $\$ 2.50$ each.

BEAUTY-BUSH. Long, arching branches with pink flowers in spring. 2 to $3 \mathrm{ft}$., $\$ 2.50$ each. DEUTZIA crenata rosea. 6 to $8 \mathrm{ft}$. Double pink with abundance of bloom in June. 2 to $3 \mathrm{ft}$.

DWARF BURNING BUSH (Euonymus alatus compacta). 4 to $5 \mathrm{ft}$. Has attractive corky
bark. Fall foliage turns bright red. 2 to $3 \mathrm{ft}$. bark. Fall $\$ 3.50$ each.

FORS YTHIA intermedia spectabilis (Golden Bell). Strong, erect habit. 2 to $3 \mathrm{ft}$., $\$ 2.50$ each. 3 to $4 \mathrm{ft}$., $\$ 3.25$.
ynwood Gold. (New.) Golden yellow flowers on erect branches. A good bloomer. 2 to $3 \mathrm{ft}$., $\$ 2.50$ each.

HYDRANGEA, Otaksa. Blue or pink, depending each.

LILAC, OId-fashioned Purple. 2 to $3 \mathrm{ft}$., $\$ 2.75$

French Hybrids.

$\begin{array}{ll}\text { Violet-red. } & \text { White. } \\ \text { Red-purple. } & \text { Light Blue. }\end{array}$

Above 4 varieties,

18 to 24 in., $\$ 3.50$ each; 2 to $3 \mathrm{ft}$, $\$ 5.00$ grant white flowers, May and June 3 to Fra$\$ 3.50$ each.

SNOWBALL tomentosum plicatum. 6 to $8 \mathrm{ft}$. autumn colorin 4 ft., $\$ 4.00$.

SPIRAEA, Anthony Waterer. Crimson flowers all summer. Dwarf. 15 to 18 in., $\$ 2.75$ each.

Vanhouttei. The most showy white variety. May, June. 2 to

VIBURNUM setigerum. Strong shrub with clusters of bright red berries that remain until early winter. 3 to $4 \mathrm{ft}$., $\$ 3.50$ each.

WEIGELA rosea. Pink flowers in May or June. 2 to $3 \mathrm{ft} ., \$ 3.25$ each.

Vaniceki. Vigorous red Weigela growing 5 to 6 to $4 \mathrm{ft}$., $\$ 3.75$.

\section{DWARF EVERGREENS}

ARBORVITAE, Globe. Globes of dense, light green foliage. 12 to 15 in., $\$ 3.50$ each. 15 to 18

Biota (Aurea nana). Grows 4 to 5 feet tall. Pyramidal and compact in form; golden yeilow in spring, turning reddish brown in winter. For
edging and formal planting. 15 to 18 in., $\$ 4.50$ each.

\section{SPREADING EVERGREENS}

JUNIPERUS chinensis Hetzi. Resembles Pfitzer Juniper, Fast-growing blue-green foliage YEW, Spreading (Taxus cuspidata). Moderately
bushy. Short dark green foliage. 12 to 15 in.,

YEW, Dwarf Spreading (Taxus cuspidata nana) Ultimate height 2 to $3 \mathrm{ft}$. Well suited to small on soil acidity. 15 to $18 \mathrm{in}$., $\$ 3.50$ each.
Peegee. The old-time variety. 2 to $3 \mathrm{ft}$., $\$ 2.50$ Showy white flowers in June with purple

\section{TALL EVERGREENS}

ARBorVItef, American Nigra. Symmetrica in form; and dark green in color. The best of the taller Arborvitae. Very compact; rapid
grower. $21 / 2$ to $3 \mathrm{ft}$., $\$ 4.75$ each. $31 / 2$ to $4 \mathrm{ft}$., growe
$\$ 7.00$.

Pyramidal. Dense dark green foliage. $21 / 2$ to $3 \mathrm{ft}$., $\$ 4.75$ each. $31 / 2$ to $4 \mathrm{ft}$., $\$ 7.00$.

CEDAR, Deodar. Tall, pyramidal tree of bluish green. A rapid grower, not hardy in far north. 24 to $30 \mathrm{in}$,, $\$ 6.00$

HEMLOCK. Best evergreen for shade. Rich deep green foliage. Can be used to make a beautifu hedge.
$\$ 6.25$.

SPRUCE, Colorado. Silvery green foliage. Tall

grower. 24 to $30 \mathrm{in} ., \$ 6.00$ each.
Glauca densata (Black Hills Spruce). Silvery foliage. More compact than Norway Spruce

YEW, Upright (Taxus media Hicksi). Symmetrical shape. Brilliant scarlet fruits. 15 to $18 \mathrm{in}$, $\$ 5.00$ each.

\section{BROAD-LEAVED EVERGREEN SHRUBS}

ABELIA grandiflora (Bush Arbutus). Leaves dark green and glossy. Flowers white, tinted AZALEA, Hinodegiri. Low-growing. Scarlet flowers; evergreen leaves. 4 to 6 in., $89 \mathrm{c}$. each.
10 to 12 in., $\$ 3.25,12$ to 15 in. $\$ 4.25$. (All 10 to 12 in., $\$ 3.25 .12$
sizes indicate spread.)

Kurume, Coral Bells. Clear pink. 4 to 6 in., 89 c. each. 10 to 12 in., \$3.25. 12 to 15 in., \$4.25 Snow. Pure white, 4 to 6 in., 89 c, each. 10 to 12 in., \$3.25. 12 to 15 in., \$4.25.

BOXWOOD, Old English (Buxus suffruticosa). Slow-growing. For edging or borders. 4 to 6
in., $75 \mathrm{c}$, each (bare root). 8 to $10 \mathrm{in},{ }^{2}, \$ 3.00$ in., 75 C.

ILEX cornuta Burfordi (Chinese Holly). A shrub to 10 feet tall. Lustrous dark greer leaves, always beautiful. Its large, bright red berries are most effective. 15 to 18 in., $\$ 3.50$

Crenata convexa. Small convex-shaped leaves Broad shrub or hedge plant, with evergreen boxwood-like foliage and black berries. 12 to 15 in., $\$ 4.25$ each.

Crenata Hetzi. 5 to $6 \mathrm{ft}$. Large convex foliage of dark glossy green, resistant to spider. 15 in., $\$ 4.75$ each.

Rotundifolia. $8 \mathrm{ft}$. Deep green color; round leaves. Very popular and useful for foundatio and hedge work. 12 to 15 in., $\$ 4.25$ each. 15 to 18 in., $\$ 5.50$.

MAHONIA Bealei. Evergreen; glossy leaves. Yellow flowers in May. Blue-black berries
Likes partial shade, 12 to 15 in., $\$ 5.00$ each. PIERIS japonica. Evergreen. Clusters of small drooping white flowers in May. 15 to 18 in.

VRACANTHA (Firethorn). The Firethorns are
valued for their profuse clusters of brilliant red valued for their profuse clusters of brilliant red
and orange berries all fall and far into the

Red Berries and Orange Berrles. 15 to $18 \mathrm{in.}$ $\$ 3.50$ each. 18 to 24 in. \$4.50.

HYBRID RHODODENDRON, Named Va rieties. Crimson, lavender to pink, red and rosy lilac. 15 to 18 in., $\$ 8.95$ each. 22 to 26 in.,
$\$ 11.95$.

All flowering shrubs and evergreens are balled and burlapped. Our plants are good heavy stock. Free delivery in Washington and the suburban area; no shipments made outside this area. Resident of $\mathrm{D}$. C. and $\mathrm{Md}$. are requested to include the $3 \%$ sales tax with their remittance. We cannot mail items on this page.

\section{ORNAMENTAL and SHADE TREES}

ASH, Mountain. Red berries. Dark green foliage. Do $\$ .50$ each.

BIRCH, White. Attractive tree with white bark. 4 to $5 \mathrm{ft}$., $\$ 6.00$ each. 5 to $6 \mathrm{ft}$., $\$ 7.50$. 6 to $8 \mathrm{ft}$. $\$ 10.00$.

BIRCH Clump. Same as above other than having 3 stems from grou 4 to $5 \mathrm{ft}$. $\$ 8.50$.

CHERRY, Flowering. Double pink flowers in spring. 3 to $4 \mathrm{ft}$., $\$ 7.50$ each.

CRAB, Flowering. Grows 15 to $20 \mathrm{ft}$. Red, pink, and white showy masses of bloom in early spring. Easy to grow. 4 to $5 \mathrm{ft}$., $\$ 5.00$ each. JUDAS TREE (Redbud). Grows 10 to $12 \mathrm{ft}$. Rosy pink flowers in April. 4 to $5 \mathrm{ft}$., $\$ 7.50$
each.
Big 4-5 ft. trees

APPLE TREES

Winter Varieties

Red Delicious. Red; fine grained. Stayman (Imp. Winesap). Large.
Yellow Delicious. Golden yellow.

Autumn Varieties

Yellow Transparent. Large yellow.

5-N-One Apple Trees. One tree with five va-

rieties. 2-yr.-old, 5 to $6 \mathrm{ft}$., $\$ 5.50$ each.

\section{CHERRY TREES
2-yr,-old, $\$ 3.25$ each}

Bing. Large, delicious black variety Montmorency. Sour. Bears last of June. Napoleon. Large; sweet. Midseason.

PEACH TREES

Belle of Georgia. Freestone; white flesh. Eiberta. Large; yellow flesh. Freestone. J.H. Hale. Golden yellow freestone.

Shipper's Late Red. Yellow freestone. Large

2-yr.-old, \$3.00 each

Bartlett. The best large eating Pear.

PLUM TREES

2-yr.-old, $\$ 3.00$ each

Abundance. The popular early cherry-red

Burbank. A well-known dark red; early.

Damson (Blue Shropshire).
Stanley. Blue. Prune type.

Caco. Large wine-red berries.
Concord. The standard black.

Niagara. White.

All Grape-Vines $\$ 1.00$ each

\section{MULTIFLORA ROSE FENCE}

Living Farm Fence of Great Value

White flowers in spring, followed by red berries. Needs no trimming. Grows 6 to 8 feet tall, 5 to 7 teets soil, crops, game. 15 to $18 \mathrm{in.,} \$ 4.75$ for 25 . $\$ 17.50$ per 100 .

\section{HEDGE PLANTS}

PRIVET, California. Dark green foliage which re mains on the plant until mid-winter. Wellbranched heavy stoc

Lucidum (Evergreen Privet). Compact plant with glossy green leaves and blue berrie:
12 to 15 in., $\$ 2.50$ each; 15 to 18 in., $\$ 3.50$.
Summer Varieties

PEAR TREES

\section{$\underset{2-y r \text {-old }}{\text { GRAPE-VINES }}$}

(Rosa multifiora) A hardy Chinese species with beautiful cupshaped flowers 3 to 5 inches in drameter, whit inside, flushed with pink out $\$ 6.50$ each. 3 to $4 \mathrm{ft}$., $\$ 8.50$.

Soulangeana nigra. Grows 15 to $18 \mathrm{ft}$. Many purple flowers in early June. Fast grower. to $3 \mathrm{ft}$., $\$ 6.50$ each. 3 to $4 \mathrm{ft}$., $\$ 9.00$.

MAPLE, Blood-leaf Japanese Dwarf. True red. 18 to $24 \mathrm{in}$., $\$ 10.00$ each. 2 to $21 / 2 \mathrm{ft}$., $\$ 12.50$.

Crimson King. Plant Patent No. 735. The best of all deep red maples. Very colorful each.

Red (Acer rubrum). A rapid-growing Maple with vivid fall coloring. This is not the Dwar ugar. A vigorous grower with bright fall coloring. 6 to 8 it., $\$ 8.00$ each. 


